\begin{tabular}{|c|c|c|}
\hline Dinamilka Journal, Vol. 1 No. 4, 2019 \\
ISSN ONLINE : 2686-2158
\end{tabular}

\title{
PENINGKATAN PENDAPATAN MELALUI PEMBUATAN NATA DE COCO DI KELURAHAN BANCARKEMBAR PURWOKERTO UTARA
}

\author{
Senny Widyaningsih ${ }^{1 *}$, Zusfahair ${ }^{1}$, Purwati ${ }^{1}$ \\ ${ }^{1}$ Jurusan Kimia, Fakultas Matematika dan Ilmu Pengetahuan Alam (MIPA), \\ Universitas Jenderal Soedirman, Purwokerto, Indonesia \\ *Corresponding Author: sennysetiadi@yahoo.com
}

Received 5 September 2019; Accepted 26 December 2019; Available online 31 December 2019

\begin{abstract}
Abstrak
Peningkatan pendapatan melalui pembuatan nata de coco telah dilakukan di Kelurahan Bancarkembar Kecamatan Purwokerto Utara Kabupaten Banyumas. Sasaran kegiatan ini adalah para pedagang jajanan sekolah. Para pedagang cenderung menggunakan bahan yang murah namun berbahaya sebagai bahan utama jualannya. Hal ini dikarenakan para penjual kebanyakan merupakan masyarakat yang berpenghasilan rendah. Upaya peningkatan pendapatan sangat diperlukan oleh mereka. Salah satu solusinya adalah dengan membina dan melatih mereka membuat makanan sehat yang dibuat dari bahan yang murah. Nata adalah salah satu makanan yang sehat yang dibuat dari bahan yang murah. Produk nata yang paling mudah pembuatannya adalah nata de coco yang dibuat dari air kelapa dengan metode fermentasi menggunakan bakteri Acetobacter xylinum. Kegiatan ini dilakukan melalui dua tahap. Tahap pertama adalah memberikan informasi melalui penyuluhan dan peragaan. Tahap kedua adalah mempraktekkan cara pembuatan nata de coco. Teknologi pembuatan nata ini dapat diterapkan pada para penjual makanan di lingkungan sekolah dasar di Kelurahan Bancarkembar Kabupaten Banyumas.
\end{abstract}

Kata kunci : bancarkembar, jajanan, nata de coco, Acetobacter xylinum

\begin{abstract}
Increased income through the making of nata de coco has been done in the Bancarkembar Village, North Purwokerto District, Banyumas Regency. The target of this activity is school food sellers. Food sellers tend to use a cheap but dangerous ingredients as the main food ingredient for selling. This is because the sellers are mostly low-income people. Efforts to increase income are needed by them. One solution is to teach and train them to make healthy food made from inexpensive ingredients. Nata is a healthy food that is made from inexpensive ingredients. Nata de coco is the easiest which is made from coconut water with a fermentation method using the bacterium Acetobacter xylinum. This activity is carried out
\end{abstract}


through two steps. The first step is to provide information through counseling and demonstration. The second step is to practice how to make nata de coco. The nata production technology can be applied to food sellers in the elementary school environment in the Bancarkembar Village, Banyumas Regency.

Keywords : bancarkembar, food, nata de coco, Acetobacter xylinum

\section{PENDAHULUAN}

Lingkungan sekolah terutama sekolah dasar adalah lingkungan yang banyak diminati para penjual makanan ringan. Anak-anak sekolah adalah sasaran para penjual makanan tersebut. Berbagai macam jenis makanan ditawarkan seperti makaroni, cilok, gorengan, dan minuman. Para penjual makanan menggunakan berbagai cara agar dagangan mereka laku dan mendapatkan untung yang besar. Kadang kala mereka tidak memperhatikan segi kebersihan dan kesehatan dari makanan yang dijual. Faktanya, kebanyakan jajanan di sekolah mengandung zat aditif yang dapat membahayakan gangguan metabolisme tubuh si kecil dan menimbulkan berbagai macam penyakit (Ratnani, 2009). Seperti yang dilansir survei Badan Pengawas Obat dan Makanan (BPOM) Indonesia melalui 886 SD di 30 kota di Indonesia, terbukti sebanyak 35\% makanan jajanan tidak memenuhi syarat. Beberapa kandungan zat yang terdapat dalam jajanan di sekolah-sekolah, yaitu formalin sebesar 27,3\%, methanol yellow sebesar 10,2\%, rhodamin (10.9\% dan boraks sebanyak 56,7\% (Rahmianti, 2013).

Para penjual makanan ini tidak mengetahui bahaya yang dapat ditimbulkan dari makanan dan minuman yang tidak sehat yang mereka jual kepada anak-anak sekolah. Meskipun mereka mengetahuinya, mereka tetap akan menjual jajanan tidak sehat tersebut. Hal ini dikarenakan para penjual kebanyakan merupakan masyarakat yang berpenghasilan rendah. Upaya peningkatan pendapatan sangat diperlukan oleh mereka. Salah satu solusinya adalah dengan membina dan melatih mereka membuat makanan sehat yang dibuat dari bahan yang murah. Nata adalah salah satu makanan yang sehat yang dibuat dari bahan yang murah. Produksi nata merupakan jenis usaha yang berpotensi untuk meningkatkan penghasilan (Kusuma et al., 012).

Nata merupakan selulosa yang dibentuk oleh bakteri Acetobacter xylinum, berkalori rendah, kadar serat 2,5\%, dan memiliki kadar air $98 \%$ (Nugroho dan Aji, 2015). Serat yang ada dalam nata tersebut sangat penting dalam proses fisiologis, bahkan dapat membantu para penderita diabetes dan memperlancar pencernaan makanan atau dalam saluran pencernaan. Oleh karena itu dapat dipakai sebagai sumber makanan kalori rendah dan untuk kepentingan diet (Putri, 2018).

Nata merupakan bahan pangan berupa jeli yang biasa dijadikan sebagai produk kaya serat yang baik bagi kesehatan. Beberapa limbah yang telah dibuat menjadi produk nata adalah limbah air kelapa menjadi nata de coco, limbah industri tahu dan tempe menjadi nata de soya, dan limbah industri tapioka menjadi nata de cassava. Produk nata ini mampu meningkatkan nilai ekonomis dari limbah-limbah tersebut. Nata-nata tersebut banyak dibutuhkan oleh industri minuman. Banyak produsen industri minuman yang bermitra dengan petani nata di desa-desa. Kapasitas produksi petani nata umumnya masih skala industri rumahan (Salim, 2011). Produk nata yang paling mudah pembuatannya adalah nata de coco yang dibuat dari air kelapa. Biasanya pedagang kelapa di pasar hanya menjual kelapanya saja dan tidak memanfaatkan airnya. Dalam sehari seorang pedagang kelapa membuang air

S. Widyaningsih et al. 2019. Peningkatan Pendapatan Melalui Pembuatan Nata De Coco Kelurahan Bancarkembar | 
kelapanya lebih dari 30 liter. Limbah ini dapat dimanfaatkan menjadi produk nata.

Teknologi pembuatan nata ini dapat diterapkan pada para penjual makanan di lingkungan sekolah dasar di Kelurahan Bancarkembar Kabupaten Banyumas. Di kelurahan Bancarkembar terdapat beberapa sekolah dasar negeri. Salah satunya adalah SDN Glempang. Penjual makanan di lingkungan sekolah ini adalah masyarakat yang tinggal di sekitar sekolah tepatnya di RT 3 RW 1 kelurahan Bancarkembar. Sekitar delapan orang warga RT 3 RW 1 berprofesi sebagai penjual makanan di SDN Glempang. Rata-rata penghasilan mereka setiap hari hanya Rp 20.000,00. Teknologi pembuatan nata ini diharapkan dapat memberi solusi pada para penjual untuk menjual makanan sehat yang murah sehingga dapat meningkatkan pendapatan. Namun, para penjual makanan ini belum memiliki pengetahuan mengenai bagaimana membuat produk nata. Oleh karena itu mereka memerlukan penyuluhan dan pelatihan bagaimana membuat produk nata.

\section{METODE PELAKSANAAN}

Kegiatan dilaksanakan di RT 3 RW 1 Kelurahan Bancarkembar, Kecamatan Purwokerto Utara, Kabupaten Banyumas dengan peserta kegiatan adalah warga yang berprofesi sebagai pedagang jajanan sebanyak 20 peserta. Metode yang digunakan terdiri dari beberapa tahap termasuk tahap persiapan dan evaluasi. Persiapan dilakukan dengan mendata para pedagang yang akan mengikuti kegiatan. Tahap berikutnya dengan menyiapkan bahan dan alat serta melakukan uji coba pembuatan nata de coco. Bahan yang digunakan adalah air kelapa, urea, cuka masak, gula pasir, dan air. Alat yang digunakan adalah panci, kompor, nampan, kertas koran, saringan, dan gelas ukur. Sedangkan kegiatan utama dilakukan dalam dua tahap. Tahap pertama adalah penyuluhan dalam suatu pertemuan dan peragaan cara pembuatan nata de coco. Tahap kedua adalah pelatihan dan praktek langsung pembuatan nata de coco.

Tahap penyuluhan dan peragaan meliputi:

1. Pengetahuan tentang makanan yang bersih dan sehat

2. Pengetahuan mengenai nata de coco

3. Pengetahuan mengenai produksi dan penjualan

4. Peragaan pembuatan nata de coco

Tahap berikutnya adalah pelatihan dan praktek pembuatan nata de coco dengan pendampingan. Pelatihan dilakukan oleh peserta menggunakan bahan dan alat yang telah disediakan. Pembuatan nata de coco memakan waktu sekitar 2 minggu, meliputi:

1. Pembuatan starter bakteri Acetobacter xylinum

2. Pembuatan nata de coco

3. Pemanenan nata de coco

4. Pengolahan nat de coco menjadi produk yang siap konsumsi

\section{HASIL DAN PEMBAHASAN}

\section{Penyuluhan dan Peragaan Pembuatan Nata de Coco}

Penyuluhan dilakukan pada suatu pertemuan yang dihadiri oleh seluruh peserta. Penyuluhan dimulai dengan memberikan kuisioner kepada peserta. Kuisioner diberikan dua kali yaitu pada awal dan akhir kegiatan. Pada pertemuan ini disampaikan mengenai 
pengetahuan tentang makan yang bersih dan sehat. Makanan yang bersih adalah adalah makanan yang diolah dengan menjaga kebersihan, baik kebersihan bahan baku maupun kebersihan peralatan yang digunakan. Sedangkan makanan yang sehat adalah makanan yang dibuat menggunakan bahan-bahan yang memenuhi syarat kesehatan diantaranya tidak menggunakan bahan kimia berbahaya sebagai aditif. Aditif yang diperbolehkan adalah bahan yang masuk dalam kategori food grade. Salah satu contohnya adalah pewarna makanan. Seringkali produsen makanan menggunakan pewarna tekstil karena pewarna yang masuk dalam kategori food grade biasanya harganya lebih mahal. Dalam pemaparan juga disampaikan bahaya penggunaan pewarna tekstil (Nastiti, 2015).

Materi berikutnya adalah nata de coco. Sebagian besar peserta sudah mengetahui dan mengenal nata de coco, namun belum mengetahui proses pembuatannya. Proses pembuatan nata de coco dipaparkan tahap demi tahap disertai dengan pemahaman istilah-istilah yang ada. Sumber bahan baku nata de coco adalah air kelapa yang bisa didapatkan dari pasar di sekitar. Pedagang kelapa biasanya hanya menjual daging buah kelapa untuk dibuat menjadi santan dan makanan lainnya dan membuang air kelapanya. Air kelapa ini dapat dimanfaatkan untuk diolah menjadi nata de coco. Peserta merupakan pedagang di lingkungan sekolahan. Anakanak sekolah menyukai jajanan berupa es. Banyak pedagang menjual minuman seperti es buah atau es sirup. Nata de coco dapat diolah menjadi minuman seperti es sirup. Bila dibandingkan dengan es sirup biasa, nata de coco memiliki keunggulan yaitu lebih sehat karena mengandung banyak serat. Materi produksi dan pemasaran juga disampaikan dalam pertemuan tersebut. Khususnya untuk pemasaran dapat dilaksanakan lebih mudah karena peserta merupakan pedagang dan terdapat beberapa sekolah dasar di sekitar lingkungan tersebut.

Pengetahuan mengenai nata de coco dilengkapi dengan peragaan pembuatannya. Peserta antusias dan aktif bertanya mengenai proses pembuatan bahkan pada tahap tertentu peserta ikut terlibat.

\section{Pelatihan dan Praktek Pembuatan Nata de Coco}

Pelatihan dan praktek pembuatan nata de coco dilakukan oleh peserta. Pengabdi hanya melakukan pendampingan. Pembuatan nata de coco dilakukan beberapa tahap sehingga memakan waktu sekitar 2 minggu. Tahap pertama adalah pembuatan starter bakteri Acetobacter xylinum. Nata de coco merupakan produk hasil fermentasi bakteri Acetobacter xylinum (sehingga dalam pembuatannya membutuhkan bateri tersebut. Untuk itu sebelum produksi nata, perlu disiapkan terlebih dahulu bakterinya. Penyiapan bakteri melalui proses fermentasi. Bakteri bisa digunakan setelah fermentasi selama seminggu (Rizal et al., 013). Setelah bakteri siap, baru dilakukan produksi nata de coco. Produksi nata de coco juga melalui proses fermentasi selama seminggu baru dapat dilakukan pemanenan nata. Praktek pembuatan ini dilakukan di rumah salah satu warga. Pelaksanaan selama dua minggu tidak dilakukan setiap hari karena pada proses fermentasi hanya dilakukan pemantauan dan menjaga kondisi tempat fermentasi berlangsung. Pemanenan dilakukan dengan cara merebus nata yang dihasilkan kemudian dilakukan pemotongan sesuai ukuran yang diinginkan seperti terlihat pada Gambar 1. Nata de coco dibuat menjadi minuman dengan penambahan gula atau sirup.

Selama pembuatan ini hal-hal yang perlu diperhatikan adalah kebersihan dan kesterilan alat-alat yang digunakan. Apabila alat-alat yang digunakan tidak steril biasanya tidak terbentuk nata. Nata yang dihasilkan dapat dilihat pada Gambar 2.

S. Widyaningsih et al. 2019. Peningkatan Pendapatan Melalui Pembuatan Nata De 


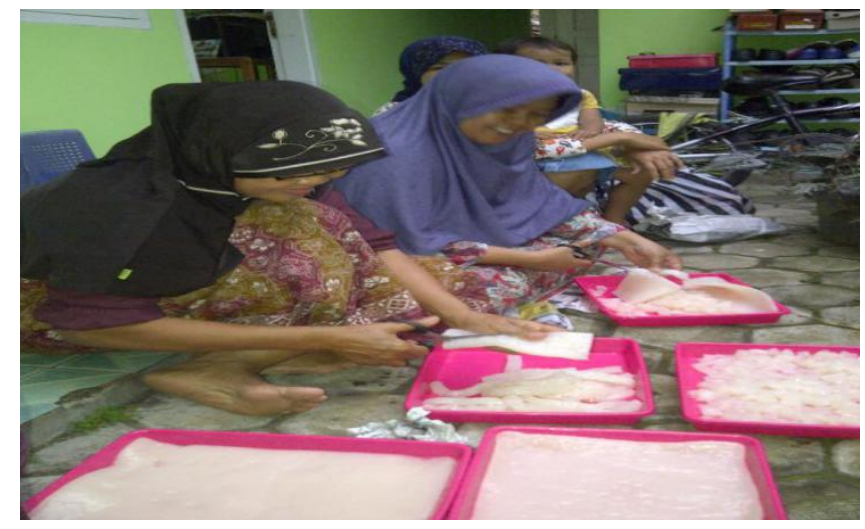

Gambar 1. Praktek pembuatan nata de coco

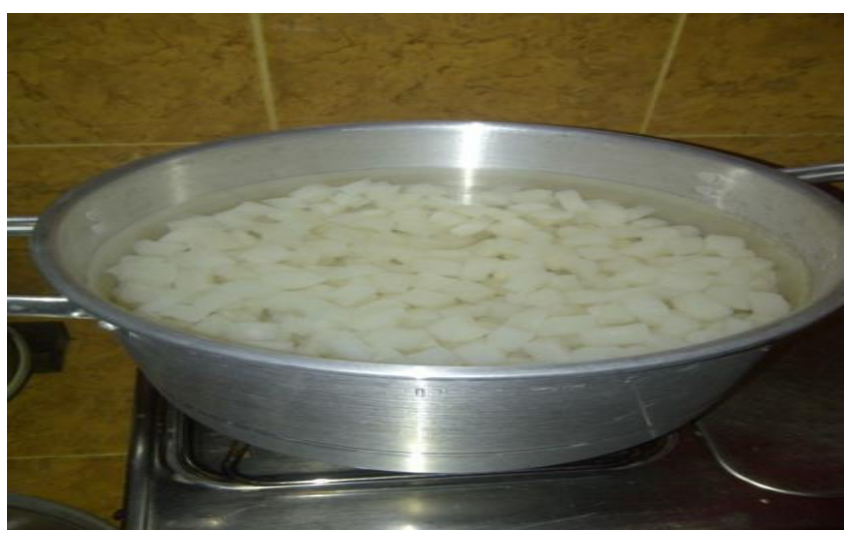

Gambar 2. Nata de coco

Saat pelatihan warga sangat antusias mengikutinya. Hal ini terlihat dari banyaknya pertanyaan mengenai pembuatan nata, seperti kegunaan gula pasir dan cuka, apakah tidak berbahaya jika menggunakan pupuk urea/ZA, mengapa peralatan harus steril, dan takarantakaran yang pas. Semua pertanyaan-pertanyaan tersebut dapat dijawab dan masyarakat puas dengan jawaban yang diberikan. Kegiatan berikutnya pembuatan nata de coco dilakukan sendiri oleh peserta tanpa pendampingan. Peserta berhasil membuat nata de coco sendiri. Evaluasi yang melalui analisa hasil akhir kuisioner menunjukkan adanya peningkatan pengetahuan peserta.

\section{KESIMPULAN}

Kegiatan ini berjalan dengan baik dan antusias peserta mengikuti kegiatan ini sangat tinggi. Secara keseluruhan warga RT 3 RW 1 Kelurahan Bancarkembar, Kecamatan Purwokerto Utara, Kabupaten Banyumas mendapatkan tambahan pengetahuan dan keterampilan membuat nata de coco setelah mengikuti ini. Motivasi yang kuat diperlukan agar warga lebih terlatih membuat nata de coco dan memproduksi nata dalam skala yang lebih besar. 


\section{UCAPAN TERIMA KASIH}

Terima kasih disampaikan kepada LPPM Universitas Jenderal Soedirman yang telah memberikan kesempatan dan biaya pelaksanaan kegiatan melalui dana BLU Universitas Jenderal Soedirman Tahun Anggaran 2014.

\section{DAFTAR PUSTAKA}

Kusuma, P.T.W.W, D.D. Hidayat, N. Irianti. 2012. Analisis Kelayakan Finansial Pengembangan Usaha Kecil Menengah (Ukm) Nata De Coco di Sumedang, Jawa Barat. Teknotan. 6 (1).

Nastiti, K. 2015. Analisis Kandungan Zat Pewarna Rhodamin B Pada Arum Manis Berdasarkan Status Ekonomi Penjual Arum Manis Di Sekolah Dasar Kecamatan Babat Kabupaten Lamongan. The Journal of Muhammadiyah Medical Laboratory Technologist. Back Issue. 1(2): 23-35.

Nugroho, D.A. P. Aji. 2015. Characterization of Nata de Coco Produced by Fermentation of ImmobilizedAcetobacter xylinum. Agriculture and Agricultural Science Procedia 3: $278-282$.

Putri, N.N. 2018. Selain Nikmat, Nata de Coco Punya Banyak Manfaat. https://health.detik.com/berita-detikhealth/d-4146250/selain-nikmat-nata-de-cocopunya-banyak-manfaat.

Rahmianti, D. 2013. Bahaya Jajanan Sekolah. Readers Digest Indonesia. http:www.readersdigest.co.id/sehat/nutrisi/bahaya.jajanan.sekolah/005/002/97.

Ratnani, R.D. 2009. Bahaya Bahan Tambahan Makanan Bagi Kesehatan. Momentum. 5 (1): $16-22$.

Rizal, H.M., D.M. Pandiangan, A. Saleh. 2013. Pengaruh Penambahan Gula, Asam Asetat Dan Waktu Fermentasi Terhadap Kualitas Nata De Corn. Jurnal Teknik Kimia. 19 (1): $34-39$.

Salim, E. 2011. Dari Limbah Menjadi Rupiah. Lily Publisher, Yogyakarta. 